\title{
Prediction of ammonia emission from dairy cattle manure based on milk urea nitrogen: Relation of milk urea nitrogen to ammonia emissions
}

\author{
S. A. Burgos, ${ }^{1}$ N. M. Embertson, ${ }^{2}$ Y. Zhao, F. M. Mitloehner, E. J. DePeters, and J. G. Fadel ${ }^{3}$ \\ Department of Animal Science, University of California, Davis 95616
}

\begin{abstract}
The main objectives of this study were to assess the relationship between ammonia emissions from dairy cattle manure and milk urea $\mathrm{N}(\mathrm{MUN} ; \mathrm{mg} / \mathrm{dL})$ and to test whether the relationship was affected by stage of lactation and the dietary crude protein $(\mathrm{CP})$ concentration. Twelve lactating multiparous Holstein cows were randomly selected and blocked into 3 groups of 4 cows intended to represent early $[123 \pm 26 \mathrm{~d}$ in milk (DIM)], mid (175 \pm 3 DIM), and late $(221 \pm 12$ DIM $)$ lactation stages. Cows within each stage of lactation were randomly assigned to a treatment sequence within a split-plot Latin square design balanced for carryover effects. Stage of lactation formed the main plots (squares) and dietary CP levels $(15,17,19$, and $21 \%$ of diet dry matter) formed the subplots. The experimental periods lasted $7 \mathrm{~d}$, with $\mathrm{d} 1$ to 6 used for adjustment to diets and $d 7$ used for total collection of feces and urine as well as milk sample collection. The feces and urine from each cow were mixed in the proportions in which they were excreted to make slurry that was used to measure ammonia emissions at $22.5^{\circ} \mathrm{C}$ over $24 \mathrm{~h}$ using flux chambers. Samples of manure slurry were taken before and after ammonia emission measurements. The amount of slurry increased by $22 \%$ as dietary CP concentration increased from 15 to $21 \%$, largely because of a greater urine volume $(25.3$ to $37.1 \mathrm{~kg} / \mathrm{d})$. Initial urea $\mathrm{N}$ concentration increased linearly with dietary $\mathrm{CP}$ from 153.5 to $465.2 \mathrm{mg} / \mathrm{dL}$ in manure slurries from cows fed 15 to $21 \%$ CP diets. Despite the large initial differences, the final concentration of urea $\mathrm{N}$ in manure slurries was less than $10.86 \mathrm{mg} / \mathrm{dL}$ for all dietary treatments. The final total ammoniacal $\mathrm{N}$ concentration in manure slurries increased linearly from 228.2 to 508.7
\end{abstract}

Received May 24, 2009.

Accepted February 15, 2010.

${ }^{1}$ Current address: Centre for Nutrition Modelling, Department of Animal and Poultry Science, University of Guelph, Guelph, ON, N1G 2W1, Canada.

${ }^{2}$ Current address: Sustainable Livestock Production Program, Whatcom Conservation District, 6975 Hannegan Road, Lynden, WA 98264 .

${ }^{3}$ Corresponding author: jgfadel@ucdavis.edu $\mathrm{mg} / \mathrm{dL}$ as dietary $\mathrm{CP}$ content increased from 15 to 21\%. Ammonia emissions from manure slurries ranged between 57 and $149 \mathrm{~g}$ of $\mathrm{N} / \mathrm{d}$ per cow and increased linearly with dietary $\mathrm{CP}$ content, but were unaffected by stage of lactation. Ammonia emission expressed as a proportion of $\mathrm{N}$ intake increased with percentage $\mathrm{CP}$ in the diet from about 12 to $20 \%$, whereas ammonia emission as a proportion of urinary urea $\mathrm{N}$ excretion decreased from 67 to $47 \%$. There was a strong relationship between ammonia emission and MUN [ammonia emission $(\mathrm{g} / \mathrm{d}$ per cow $)=25.0( \pm 6.72)+5.03( \pm 0.373)$ $\left.\times \operatorname{MUN}(\mathrm{mg} / \mathrm{dL}) ; \mathrm{R}^{2}=0.85\right]$, which was not different among lactation stages. Milk urea $\mathrm{N}$ concentration is one of several factors that allows prediction of ammonia emissions from dairy cattle manure.

Key words: milk urea nitrogen, urinary urea nitrogen excretion, ammonia emission

\section{INTRODUCTION}

Ammonia volatilization is a process in which the $\mathrm{N}$ in animal manure (urine and feces) is released into the atmosphere via biochemical and mass transfer reactions. The primary pathway for ammonia volatilization from manure begins with the hydrolysis of urinary urea to $\mathrm{NH}_{3}$ and $\mathrm{CO}_{2}$, which is catalyzed by the activity of urease, an enzyme produced by microorganisms that is found in both feces and in soil (Muck and Steenhuis, 1980). Once hydrolyzed, ammonia in aqueous solution is present as both $\mathrm{NH}_{4}{ }^{+}$and $\mathrm{NH}_{3}$, which are coupled in equilibrium by a dissociation reaction. The equilibrium between the volatile $\mathrm{NH}_{3}$ and nonvolatile $\mathrm{NH}_{4}{ }^{+}$fractions is temperature and $\mathrm{pH}$ dependent. The volatilization of ammonia occurs via convective mass transfer from the boundary layer of the manure slurry to the air above the surface. The equilibrium of ammonia between the manure slurry and the air above the surface is approached by ammonia volatilization and is dependent on the temperature and air velocity at the slurry-air boundary (Monteny and Erisman, 1998).

Because the initial step of ammonia volatilization is irreversible, under normal $\mathrm{pH}$ conditions, the amount of ammonia emitted should be determined by its production rate (Muck, 1982). The rate of urea hydrolysis, 
and thus the ammonia production rate, is determined by the amount of urea excreted in urine as well as the urease activity. Urea availability is the limiting factor for ammonia production because urease activity on commercial dairies is high (Monteny and Erisman, 1998). Urea accounts for 50 to $90 \%$ of the $\mathrm{N}$ in cattle urine (Bristow et al., 1992) and, with the exception of urine ammonia, has the highest ammonia volatilization potential of the N-containing compounds in urine (Bussink and Oenema, 1998). Accordingly, several studies reported that in dairy cattle, ammonia emissions were linearly dependent on urinary urea $\mathrm{N}$ (UUN) excretion (g/d per cow; Elzing and Monteny, 1997; James et al., 1999; Cassel et al., 2005).

Urea is produced mainly in the liver as a means of detoxification of ammonia present in the systemic circulation, which is produced by AA catabolism and ruminal microorganisms as they metabolize dietary $\mathrm{N}$ compounds consumed by ruminants (DePeters and Ferguson, 1992). Blood urea rapidly equilibrates with milk (Gustafsson and Palmquist, 1993) so that its concentration in blood and milk are closely associated (Broderick and Clayton, 1997). Blood urea is then filtered by the kidneys for excretion in urine. Dietary factors that affect the efficiency of $\mathrm{N}$ utilization by ruminal microorganisms, such as ruminal degradability of carbohydrate and protein sources, may influence UUN excretion (Sannes et al., 2002; Broderick et al., 2008). The amount of urea excreted in urine may also be affected by factors that influence urine volume, such as $\mathrm{N}, \mathrm{Na}$, and K intake (Bannink et al., 1999). Milk urea $\mathrm{N}$ has emerged as a potentially useful tool to predict $\mathrm{N}$ excretion in urine and $\mathrm{N}$ utilization efficiency in lactating dairy cows (Jonker et al., 1998; Kauffman and St. Pierre, 2001). We recently examined the relationship between MUN and UUN excretion over a wide range of dietary CP levels and found that UUN excretion was linearly related to MUN when its concentration was $\leq 25 \mathrm{mg} / \mathrm{dL}$ (Burgos et al., 2007).

We hypothesized that UUN excretion is proportional to MUN and that, under conditions in which urease activity is not limiting and environmental conditions in which ammonia dissociation and mass transfer (i.e., temperature, $\mathrm{pH}$, and air velocity) remain relatively constant, ammonia emissions from dairy cattle manure slurry is proportional to UUN excretion. The overall objective of the study was to evaluate the potential of MUN as a predictor of ammonia emissions from dairy cattle manure. The specific objectives of the experiment described herein were to assess the relationship between ammonia emissions with UUN excretion and MUN to test whether these relationships, as well as manure slurry composition and ammonia emissions, were affected by stage of lactation or dietary CP content.

\section{MATERIALS AND METHODS}

\section{Cows, Experimental Design, and Diets}

Twelve lactating multiparous Holstein cows were randomly selected and blocked into 3 groups of 4 cows intended to represent (mean \pm SD) early $(123 \pm 26$ $\mathrm{DIM})$, mid $(175 \pm 3 \mathrm{DIM})$, and late $(221 \pm 12 \mathrm{DIM})$ lactation stages. Cows within each stage of lactation were randomly assigned to a treatment sequence within a split-plot Latin square design balanced for carryover effects. Stage of lactation formed the main plots, and dietary CP levels $(15,17,19$, and $21 \%$ diet DM) formed the subplots. The ingredient and nutrient composition of the experimental diets are shown in Table 1 . The experimental periods lasted $7 \mathrm{~d}$, with d 1 to 6 used for adjustment to diets and $\mathrm{d} 7 \mathrm{used}$ for total collection of urine and feces as well as milk sample collection.

Cows were milked daily at approximately 0630 and $1830 \mathrm{~h}$ and fed at 0700 and $1900 \mathrm{~h}$ throughout the experiment. Cows were housed in individual pens measuring $6.1 \times 4.6 \mathrm{~m}$ during $\mathrm{d} 1$ to 6 of the experimental period. On d 7, cows were moved to individual pens fitted with rubber mats modified to create a tie-stall arrangement. All experimental procedures were approved by the Institution Animal Care and Use Committee at the University of California, Davis.

\section{Sample Collection}

Sample collection procedures were described in detail elsewhere (Burgos et al., 2007). Briefly, amounts of feed offered and orts were measured daily for each cow throughout the experiment and daily samples were pooled by period. Proportional milk samples from consecutive evening and morning milkings were composited by cow and analyzed for urea. Urine was collected using indwelling Foley catheters draining into plastic jugs embedded in ice-cold water tubs. Urine volume was measured for 4 consecutive intervals of approximately $6 \mathrm{~h}$. Before each milking, feces were manually cleared from cows' rectum and collected. Cows were then stimulated to urinate and urine was collected. Catheters were then clamped shut and cows were led to the milking parlor, milked, and immediately returned to their stalls; the tubing was reconnected to the catheters. From each collection interval, an aliquot was kept at $4^{\circ} \mathrm{C}$ and used to create a weighted composite sample to represent the 24 -h period. The $24-\mathrm{h}$ urine collection period is short but was selected because the urine was needed immediately for the collection of ammonia and a longer collection time would require urine to be stored for longer periods of time before the measurement of ammonia, further increasing the risk of a degraded sample. Also, 
Table 1. Ingredient and nutrient composition of experimental diets varying in protein concentration $(15,17$, 19 , and $21 \%$ dietary $\mathrm{CP}$ ) fed to lactating dairy cows from which urine and feces were collected

\begin{tabular}{lcrrr}
\hline Component, \% of DM unless noted & 15 & 17 & 19 & 21 \\
\hline Ingredient & & & & \\
Alfalfa hay, chopped & 32.2 & 31.9 & 31.6 & 31.4 \\
Oat hay, chopped & 12.0 & 12.0 & 11.8 & 11.7 \\
Corn, steam-flaked & 18.7 & 18.5 & 18.3 & 18.3 \\
Almond hulls & 17.1 & 17.0 & 16.9 & 16.7 \\
Barley, steam-rolled & 7.4 & 7.3 & 7.3 & 7.2 \\
Whole cottonseed & 6.2 & 6.1 & 6.1 & 6.0 \\
Molasses, cane & 2.5 & 2.5 & 2.5 & 2.4 \\
Fat, yellow grease & 2.2 & 2.2 & 2.2 & 2.2 \\
Urea, prilled & 0 & 0.8 & 1.6 & 2.4 \\
Salt, trace mineral & 1.7 & 1.7 & 1.7 & 1.7 \\
Nutrient & & & & \\
CP & 15.1 & 16.6 & 18.6 & 20.7 \\
Soluble protein & 4.6 & 5.4 & 8.3 & 9.6 \\
NDF & 22.0 & 22.3 & 22.5 & 22.6 \\
ADF & 31.9 & 32.1 & 32.3 & 32.3 \\
Ash & 7.13 & 7.11 & 6.99 & 7.34 \\
NE ${ }^{1}{ }^{\text {Mcal } / \mathrm{kg}}$ & 1.56 & 1.56 & 1.55 & 1.55 \\
Ca & 0.71 & 0.67 & 0.64 & 0.67 \\
P & 0.34 & 0.32 & 0.30 & 0.31 \\
Mg & 0.42 & 0.42 & 0.40 & 0.40 \\
K & 1.67 & 1.72 & 1.77 & 1.69 \\
Na & 0.32 & 0.30 & 0.31 & 0.30 \\
\hline
\end{tabular}

${ }^{1}$ Calculations based on NRC (1989).

the 12 animals in this experiment were fed the same diet treatment, which would increase the precision and improve the accuracy for this short collection period. The efficacy of the urine preservation procedure was determined in preliminary experiments in which almost $100 \%$ of urea was recovered compared with recovery achieved using acid-treated urine (Burgos et al., 2007). A portion of the urine composite sample was used for subsequent ammonia emission measurements, which were done immediately at the end of the 24 -h collection period whereas the remaining fraction was analyzed immediately for urea. Feces were collected on plastic sheeting behind the rubber mat within each stall and weighed. Fecal samples were taken before the end of each urine collection interval, stored at $4^{\circ} \mathrm{C}$ in sealed plastic bags, and used to create a weighted composite sample for ammonia emission measurements.

\section{Flux Chamber for Ammonia Emission Measurement}

Ammonia emissions from manure slurries were measured using a flux chamber system described by Sun et al. (2008) (Figure 1). The 4 flux chambers (Odotech Inc., Montreal, Quebec, Canada) were built from acrylic resin with a volume of 64.5 L. Each chamber consisted of a cylindrical enclosure with a spherical top. Perforated Teflon tubing (50 cm, $6.35 \mathrm{~mm}$ o.d.) installed around the inside circumference of the chamber allowed pure, ammonia-free air to circulate throughout the chamber when connected to a compressed air distribution system. Each chamber contained 2 ports, one for extracting sample air and one for measuring internal temperature with a thermocouple. In addition, an opening on the top of the chamber allowed excess air to escape during equilibration or sampling to equalize inside pressure. A square piece of Teflon sheet was used underneath the flux chambers to minimize absorption of the emitted gases by the counter surface. The chamber was sealed to the surface with an inert benonite compound to ensure no outside air contamination. The flux chamber system was set up in a temperature-controlled room such that all measurements were conducted at a constant temperature of $22.5^{\circ} \mathrm{C}$.

Weighted composite fecal and urine samples were brought to room temperature in sealed containers, combined in proportion [(wt/wt); wet basis] to the urine and feces excreted by each animal, and thoroughly mixed together in a homogenizer to ensure a homogeneous slurry. The slurry $(1 \mathrm{~kg})$ was placed in circular trays with a diameter of $27 \mathrm{~cm}$ and a height of $5.1 \mathrm{~cm}$. The flux chambers were assigned to each animal such that each flux chamber had the slurry of each animal, treatment, and stage of lactation. The depth of the slurry in the tray was approximately 2 $\mathrm{cm}$, which simulates the depth of the slurry in free stall barns (Sun et al., 2008). Airflow through the system was started after a flux chamber was placed over the well plate and sealed to the Teflon sheet. The air inside the flux chamber was continuously replaced with clean air at a rate of $10 \mathrm{~L} / \mathrm{min}$. Ammonia was collected with 


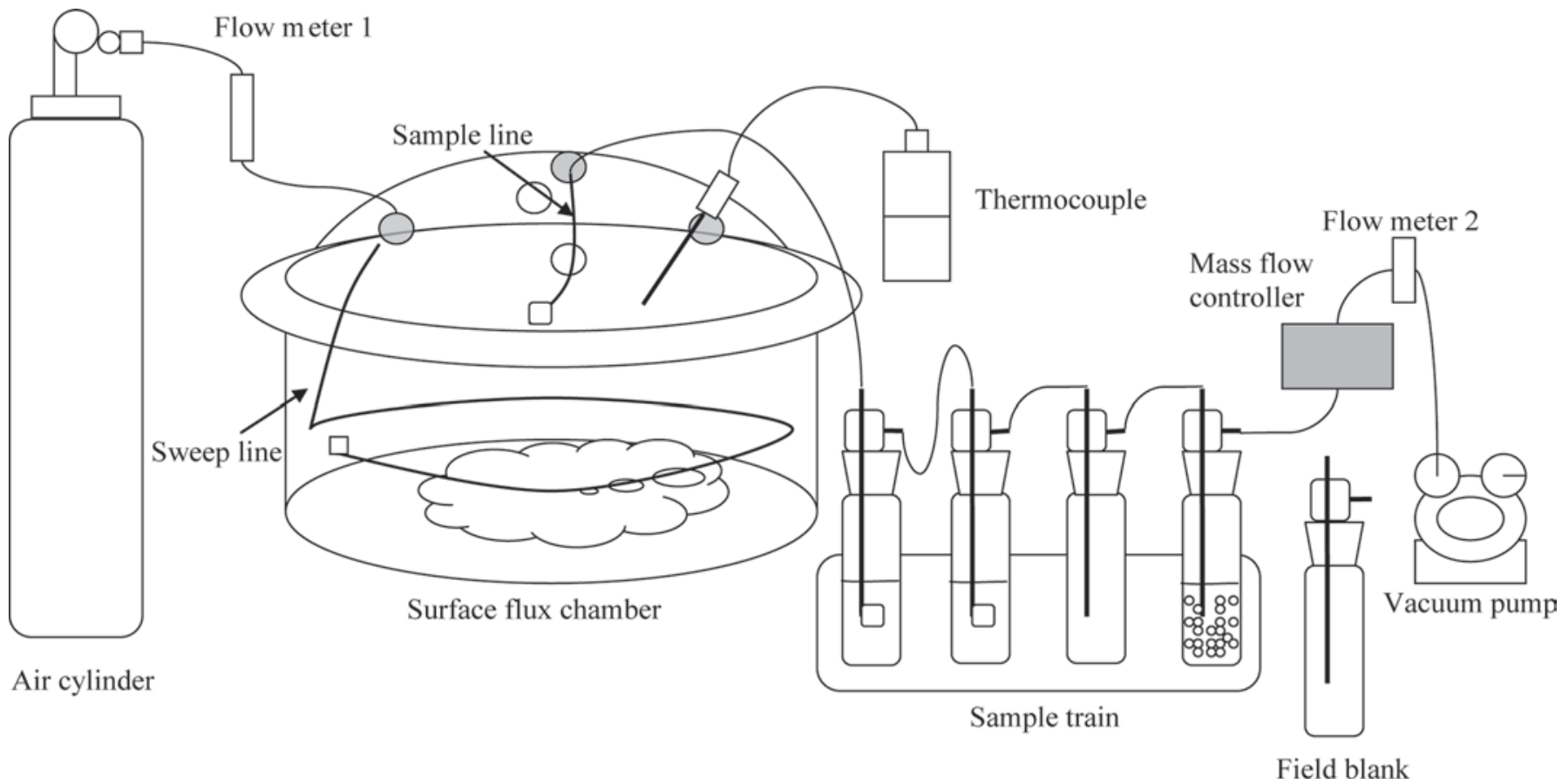

Figure 1. Schematic diagram of flux chamber system used to measure ammonia emissions with an air cylinder, 2 flow meters, 1 thermocouple, 4 active impingers, 1 field blank impinger, a mass flow controller, and a vacuum pump.

an impinger sampling train connected to the sampling port of the flux chamber (Figure 1). The sampling train consisted of 2 midget bubblers and 2 midget impingers (Kimble/Kontes, Vineland, NJ). The first 2 impingers each contained $15 \mathrm{~mL}$ of $0.1 \mathrm{~N} \mathrm{H}_{2} \mathrm{SO}_{4}$. The first bubbler captured most ( $99 \%$ ) of the ammonia from the sample source. The second bubbler retained any surplus ammonia not captured by the first bubbler. The third impinger was empty to trap any overflow of $\mathrm{H}_{2} \mathrm{SO}_{4}$. The fourth impinger was filled with $15 \mathrm{~mL}$ of tarred silica gel (6-12 mesh). A field blank impinger was used to absorb any background ammonia from the sampling room environment. Sampling ports between impingers were connected with $10 \mathrm{~cm}$ of Tygon tubing $(6.35 \mathrm{~mm}$ i.d.; Saint-Gobain Performance Plastics Corp., Akron, $\mathrm{OH})$. The sampling train was assembled in a test tube rack for stability and placed into a plastic container containing sufficient crushed ice to cover the $15-\mathrm{mL}$ line of the impingers. Air was pulled through the sampling train at a rate of $1 \mathrm{~L} / \mathrm{min}$. Flow was controlled at a steady rate using a mass flow controller with a backup flow meter for verification. After a 26-min equilibration period, air was sampled for $32 \mathrm{~min}$. This initial ammonia sample was considered the zero time. Additional samples were taken in a similar fashion to time zero at $2,4,8$, and $24 \mathrm{~h}$ after an initial mixing.

Ammonia emission rates (g of $\mathrm{N} / \mathrm{m}^{2}$ per hour) were calculated as $\mathrm{FD} / \mathrm{A}$, where $\mathrm{F}$ is the liters of ammonia per hour, D is the conversion of liters of ammonia to grams of $\mathrm{N}$ adjusting for temperature at sampling, and A is the exposed surface area of the sample in squared meters. The ammonia emissions for a given time frame were calculated as FDt, where $t$ is the time frame of sampling. Ammonia emission (g of N/d per cow) was determined by interpolation between sampling times over $24 \mathrm{~h}$ and then back-calculated to represent the emission from the waste of each animal. Ammonia emission was also expressed as a percentage of $\mathrm{N}$ intake and UUN excretion.

Slurry samples and $\mathrm{pH}$ measurements were taken just before the flux chamber was placed over the circular tray containing slurry and immediately after it was removed and were designated as initial and final measurements, respectively. The slurry $\mathrm{pH}$ was measured using a Thermo Orion Perphect $\mathrm{pH}$ meter (model no. 320, Thermo Orion, Beverly, MA) with an Accumet pH combination electrode (Fisher Scientific, Pittsburgh, $\mathrm{PA})$.

\section{Analytical Procedures}

Chemical analyses of the feeds were described in Burgos et al. (2007). Urine, milk, and manure slurry samples were assayed for urea $\mathrm{N}$ concentration by a diacetyl monoxime method (Marsh et al., 1957). Total ammoniacal N (TAN) in manure slurry was analyzed 
using automated colorimetry (Noel and Hambleton, 1976). Ammonium $\mathrm{N}$ in acid traps from flux chambers was analyzed using EPA method 300 (Pfaff, 1993) ion chromatography (Dionex ICS90, Dionex Corp., Sunnyvale, CA) as described previously (Sun et al., 2008).

\section{Statistical Analysis}

Properties and composition of manure slurries and ammonia emission measurements were analyzed using PROC MIXED of SAS (SAS Institute, 1999) according to the following model:

$$
\mathrm{Y}_{\mathrm{ijkl}}=\mu+\mathrm{S}_{\mathrm{i}}+\mathrm{c}_{\mathrm{j}(\mathrm{i})}+\mathrm{P}_{\mathrm{k}}+\mathrm{L}_{\mathrm{l}}+\mathrm{SL}_{\mathrm{il}}+\mathrm{E}_{\mathrm{ijkl}},
$$

where $Y_{\mathrm{ijkl}}=$ dependent variable measured for the ith stage of lactation, the jth cow within the ith stage of lactation, during the kth period, and the lth level of dietary $\mathrm{CP}$ content; $\mu=$ overall mean; $\mathrm{S}_{\mathrm{i}}=$ fixed effect of the ith stage of lactation, $\mathrm{i}=1,2,3 ; \mathrm{c}_{\mathrm{j}(\mathrm{i})}=$ random effect of the jth cow within the ith stage of lactation, $\mathrm{j}=1,2,3,4 ; \mathrm{P}_{\mathrm{k}}=$ fixed effect of the kth period, $\mathrm{k}=$ $1,2,3,4 ; \mathrm{L}_{1}=$ fixed effect of the lth level of dietary $\mathrm{CP}$ content, $\mathrm{l}=1,2,3,4 ; \mathrm{SL}_{\mathrm{il}}=$ interaction term of the ith stage of lactation with the lth level of dietary $\mathrm{CP}$ content; and $\mathrm{E}_{\mathrm{ijkl}}=$ error term $\sim \mathrm{N}\left(0, \sigma_{\mathrm{e}}{ }^{2}\right)$. Linear and quadratic effects of $\mathrm{CP}$ level were estimated by orthogonal contrast (Littell et al., 1996). Ammonia emissions over time were analyzed using the repeated measures model as described previously (Burgos et al., 2007). Flux chamber was initially considered a main effect but was removed from the models because it was not significant in all cases.

To determine the effect of stage of lactation on the relationships between ammonia emissions and UUN excretion as well as MUN concentration, a sequence of mixed models was fitted using the same procedure described previously (Burgos et al., 2007). The final model was the same for both relationships and did not include period or stage of lactation effects because they were not significant. Also, because cow was a random effect, the models reduced to equations with a dependent and independent variable with an overall intercept.

\section{RESULTS AND DISCUSSION}

\section{Milk Production and Composition}

The details of the milk production and composition were described previously (Burgos et al., 2007). Averages are described below because no differences were found between the CP treatments. Briefly, yields $(\mathrm{kg} / \mathrm{d})$ of milk, fat, protein, lactose, and SNF were 30, 1.29, $0.87,1.50$, and 2.70 , respectively. The composition for fat, protein, lactose, and SNF percentages were 4.09, $2.89,4.82$, and 8.87 , respectively.

\section{Manure Slurry Characteristics}

The interaction between stage of lactation and level of dietary $\mathrm{CP}$ content was not significant for any manure characteristic and composition measurements $(P$ $=0.36$ to 0.98 ); therefore, only the tests on main effects are presented (Table 2). None of the manure measurements were affected by stage of lactation $(P>0.19)$ except for feces excretion, which tended to decrease $(P$ $=0.07)$ as lactation progressed.

The amount of slurry increased by $22 \%$ as dietary CP content increased $(P<0.001)$ from 15 to $21 \%$ (Table 2 ). This effect was largely attributable to a greater urine volume $(25.3$ to $37.1 \mathrm{~kg} / \mathrm{d} ; P<0.001)$ because excretion of feces did not change in response to the higher $\mathrm{CP}$ content of the diet $(P=0.84)$. These findings agree with those reported by Sannes et al. (2002), who observed that urinary excretion increased from 22.2 to $25.6 \mathrm{~L} / \mathrm{d}$ when dietary $\mathrm{CP}$ was increased from 17.2 to $19.1 \%$. Colmenero and Broderick (2006) estimated urine volumes of 15.4 and $21.7 \mathrm{~L} / \mathrm{d}$ from cows fed diets containing 15 and $19.4 \% \mathrm{CP}$, respectively. As the amount of urine excreted increased in response to higher dietary CP levels (Table 2), the proportion of urine in manure slurry increased from 0.74 to $1.06(P$ $<0.001)$ with a concomitant $13 \%$ reduction in the manure slurry DM content $(P<0.001)$. Consistent with these results, van der Stelt et al. (2008) reported that the DM content of manure slurries was $15 \%$ greater when the protein content of the diet decreased from 19 to $11 \%$.

Initial urea $\mathrm{N}$ concentration (Table 2) increased linearly with dietary $\mathrm{CP}$ and was almost 3 times higher in manure slurries from cows fed diets containing $21 \% \mathrm{CP}$ relative to those containing $15 \% \mathrm{CP}(P<0.001)$. This was likely the result of the greater proportion of urine in slurry and a higher UUN concentration (Burgos et al., 2007). Despite the large differences in initial urea $\mathrm{N}$ concentration in manure slurry, urea $\mathrm{N}$ was almost completely lost within $24 \mathrm{~h}$ at $22.5^{\circ} \mathrm{C}$ (Table 2). Our results are in agreement with Muck (1982), who reported that $95 \%$ of urea in urine hydrolyzes within $6 \mathrm{~h}$ at $30^{\circ} \mathrm{C}$ and within $24 \mathrm{~h}$ at $10^{\circ} \mathrm{C}$. Our findings suggest that under the conditions of the current study, urease activity in manure slurry was not limiting for ammonia emissions.

There was no significant effect of CP levels on initial TAN in manure slurry (Table 2), although a quadratic trend was evident $(P=0.053)$. The final manure slurry TAN increased from 228.2 to $508.7 \mathrm{mg} / \mathrm{dL}$ as dietary $\mathrm{CP}$ content went from 15 to $21 \%$. Initial urea N concen- 
Table 2. Means for total manure slurry weights, urine weights, feces weights, slurry composition, and $\mathrm{pH}$ of manure slurries derived from urine and fecal samples collected from lactating dairy cows at different lactation stages fed diets varying in protein concentration

\begin{tabular}{|c|c|c|c|c|c|c|c|c|c|c|c|c|}
\hline Item & \multicolumn{3}{|c|}{ Stage of lactation (SOL) } & SEM-SOL & \multicolumn{4}{|c|}{ Dietary CP, $\%$ of DM } & SEM-CP & \multicolumn{3}{|c|}{$P$-value ${ }^{1}$} \\
\hline Total slurry, $\mathrm{kg} / \mathrm{d}$ & 73.4 & 65.8 & 62.3 & 5.39 & 59.4 & 67.7 & 68.8 & 72.7 & 3.48 & 0.362 & $<0.001$ & 0.227 \\
\hline Urine, $\mathrm{kg} / \mathrm{d}$ & 32.3 & 30.8 & 32.0 & 3.34 & 25.3 & 30.0 & 34.3 & 37.1 & 2.17 & 0.946 & $<0.001$ & 0.419 \\
\hline Feces, $\mathrm{kg} / \mathrm{d}$ & 41.1 & 35.0 & 30.2 & 2.86 & 34.1 & 37.7 & 34.4 & 35.5 & 1.91 & 0.069 & 0.839 & 0.263 \\
\hline Initial urea $\mathrm{N}, \mathrm{mg} / \mathrm{dL}$ & 273.5 & 312.0 & 292.9 & 25.14 & 153.5 & 224.1 & 328.4 & 465.2 & 22.53 & 0.577 & $<0.001$ & 0.104 \\
\hline Final urea N, mg/dL & 10.58 & 10.01 & 9.78 & 0.43 & 9.50 & 9.72 & 10.41 & 10.86 & 0.42 & 0.437 & 0.012 & 0.776 \\
\hline Initial $\mathrm{TAN}^{3}{ }^{3} \mathrm{mg} / \mathrm{dL}$ & 53.44 & 47.13 & 34.94 & 9.36 & 32.00 & 61.58 & 50.42 & 36.67 & 10.81 & 0.375 & 0.954 & 0.053 \\
\hline Final TAN, mg/dL & 354.9 & 390.3 & 343.8 & 20.78 & 228.2 & 312.8 & 402.2 & 508.7 & 19.80 & 0.305 & $<0.001$ & 0.549 \\
\hline Initial $\mathrm{pH}$ & 7.85 & 7.93 & 7.88 & 0.04 & 7.90 & 7.90 & 7.86 & 7.89 & 0.04 & 0.440 & 0.652 & 0.605 \\
\hline Final pH & 8.53 & 8.52 & 8.53 & 0.04 & 8.11 & 8.49 & 8.69 & 8.82 & 0.04 & 0.986 & $<0.001$ & 0.007 \\
\hline
\end{tabular}

${ }^{1}$ Probability of a significant effect of stage of lactation or a linear or quadratic effect of dietary CP.

${ }^{2}$ Effect of dietary $\mathrm{CP} ; \mathrm{L}=$ linear and $\mathrm{Q}=$ quadratic trends.

${ }^{3} \mathrm{TAN}=$ total ammoniacal $\mathrm{N}$.

tration in manure slurry was directly proportional to the final TAN, consistent with urea hydrolysis driving TAN concentration in manure slurry.

The initial $\mathrm{pH}$ in the manure slurries was not different for $\mathrm{CP}$ level of the diet and ranged between 7.86 and $7.92(P=0.652)$. Previous studies (Paul et al., 1998; Kröber et al., 2000) reported higher initial $\mathrm{pH}$ values in manure slurries from cows fed a higher concentration of $\mathrm{CP}$ in the diet. Slurry $\mathrm{pH}$ was largely determined by the relative concentrations of VFA and TAN, and $\mathrm{pH}$ increased as the VFA:TAN ratio decreased (Paul and Beauchamp, 1989). Volatile fatty acids in manure slurries were not measured in the current study, but the disparity between our results and those of others may relate to differences in how the diet affected the relative concentrations of VFA and TAN in manure slurry. Manure slurry $\mathrm{pH}$ at $24 \mathrm{~h}$ increased quadratically in response to a linear increase in dietary $\mathrm{CP}$ content $(P=$ 0.007). The quadratic relationship may be explained by the fact that $\mathrm{pH}$ is expressed in a logarithmic scale. If all the ammonia in the manure slurry were volatilized, then one would expect the $\mathrm{pH}$ to decrease, but there are sufficient $\mathrm{NH}_{4}{ }^{+}$ions to keep the $\mathrm{pH}$ below the $\mathrm{pK}$ of this reaction. This supports the observation that high TAN levels are associated with increased slurry pH.

\section{Ammonia Emissions}

Ammonia emissions ranged from 57 to $149 \mathrm{~g}$ of N/d per cow and increased linearly with dietary CP content $(P<0.001$; Table 3$)$. This was anticipated because substantial evidence in the literature supports higher ammonia emissions with increasing CP intake by dairy cows (Frank and Swensson, 2002; van der Stelt et al.,
2008). Ammonia emissions from dairy cattle were previously measured under a wide variety of conditions (e.g., dietary treatments and seasons) and methodologies, including laboratory setups (James et al., 1999; Frank and Swensson, 2002; Misselbrook et al., 2005), tie-stall dairy barns or cow houses (Elzing and Monteny, 1997; van Duinkerken et al., 2005; Powell et al., 2008), and open-lot dairies (Cassel et al., 2005). These differences make direct comparisons among studies difficult. Nevertheless, from the data presented by Frank and Swensson (2002) it can be calculated that between 56 and $163 \mathrm{~g}$ of $\mathrm{NH}_{3}-\mathrm{N} / \mathrm{d}$ per cow was emitted from lactating Swedish Holstein manure, in agreement with the current study. Most literature values of ammonia emissions per cow from tie-stalls are lower and range from 5 to $35 \mathrm{~g}$ of $\mathrm{N} / \mathrm{d}$ per cow (Powell et al., 2008). It is possible that constant laboratory conditions result in higher ammonia emissions than those measured under field conditions. However, average ammonia emissions of $50 \mathrm{~g}$ of $\mathrm{N} / \mathrm{d}$ per cow, with a range of 19 to $143 \mathrm{~g}$ of $\mathrm{N} / \mathrm{d}$ per cow, from an open-lot dairy farm (Cassel et al., 2005) are within the range of the ammonia emissions in the current study. Based on their findings, our measurements may be a reasonable approximation of ammonia emissions by dairy cows in open-lot dairies. Further studies will be required to establish reliable estimates of ammonia emission by dairy cattle under different nutritional and environmental conditions.

Ammonia emission from manure slurries as a function of time is presented in Figure 2. There was an interaction $(P<0.001)$ between dietary $\mathrm{CP}$ content and time of sampling for ammonia emissions. Ammonia emissions from manure slurries from dairy cows fed diets varying in protein concentration (15 to $21 \%$ ) were 


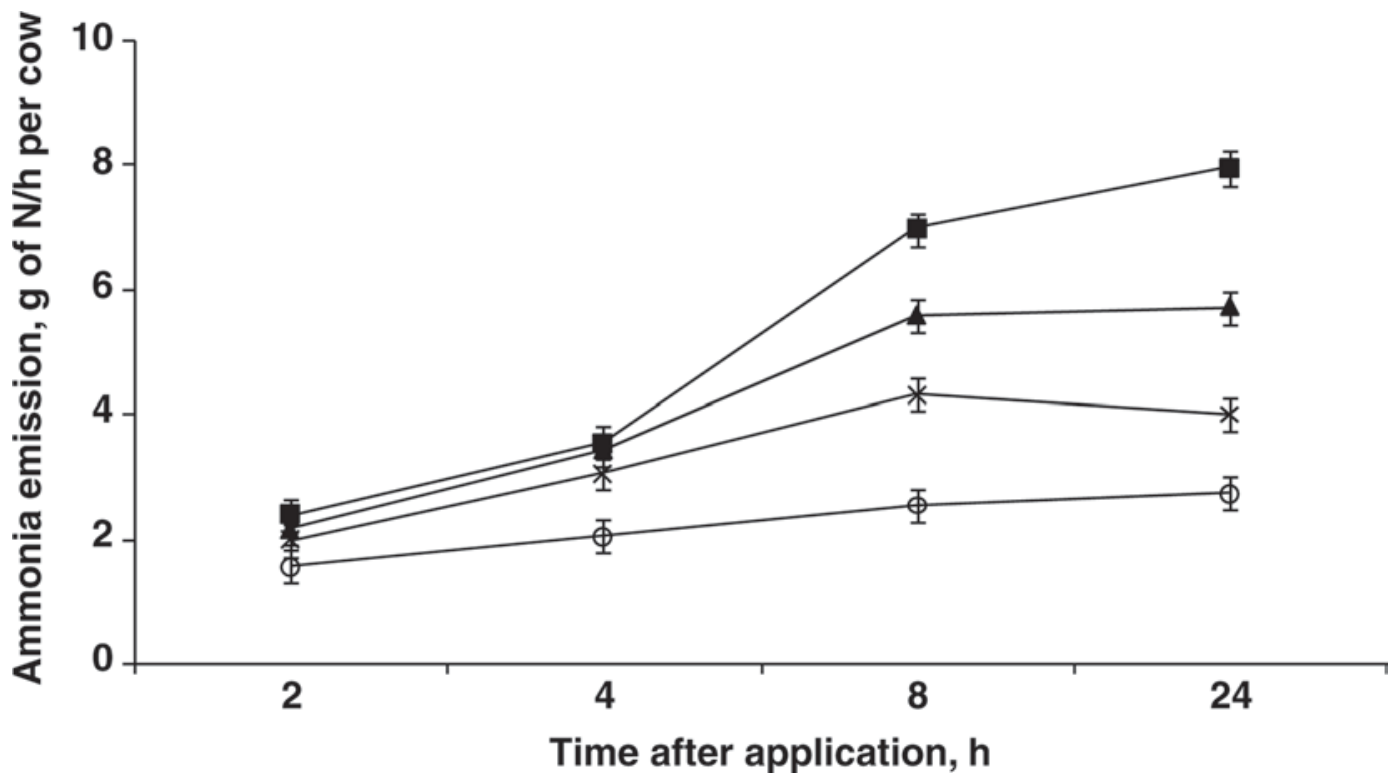

Figure 2. Ammonia emission ( $\mathrm{g}$ of $\mathrm{N} / \mathrm{h}$ per cow) versus time after application at 4 levels of dietary CP: $15(\bigcirc), 17(\times), 19(\mathbf{\Lambda})$, and $21 \%$

similar at the earliest sampling time, but by $8 \mathrm{~h}$ after the initial samples were taken, ammonia emissions from slurries derived of urine and feces of cows fed $21 \% \mathrm{CP}$ were almost 3 times greater than those of cows fed $15 \%$ $\mathrm{CP}$. The rate of ammonia emission by manure slurries from dairy cows fed the highest CP content continued to increase at least up to $24 \mathrm{~h}$, whereas the emission rate by the 3 remaining slurries remained at similar levels with respect to the 8-h level. In the study by James et al. (1999), ammonia emission from manure slurries was maximal at 10 to $15 \mathrm{~h}$ after urine and feces were combined, similar to the time frame observed in the current study. The time course of ammonia emissions from dairy slurries is consistent with the concept in which at earlier time points, urea hydrolysis may have been rate determinant for ammonia emissions, but as time progressed and urea was quickly degraded, TAN began to accumulate in slurry, making convective mass transfer of ammonia from the slurry-air boundary rate limiting for emission.

Ammonia emission expressed as a percentage of $\mathrm{N}$ intake increased linearly $(P<0.001)$ with percentage of $\mathrm{CP}$ in the diet (Table 3). The maximal ammonia emissions ranged from about 12 to $20 \%$ of the $\mathrm{N}$ consumed. Ammonia emissions as a proportion of UUN excretion decreased linearly $(P<0.001)$ from 67 to $47 \%$ as $\mathrm{CP}$ in the diet increased from 15 to $21 \%$ (Table 3). Although ammonia emissions increased with increasing dietary $\mathrm{CP}$ content, the proportion of ammonia emitted from urinary urea declined. We suggest that the decline in this ratio may be attributable to the time frame selected to measure ammonia emissions and that if the experi-

Table 3. Means for ammonia emissions by manure slurries from lactating dairy cows at different lactation stages fed diets varying in protein concentration

\begin{tabular}{|c|c|c|c|c|c|c|c|c|c|c|c|c|}
\hline Ammonia emission & \multicolumn{3}{|c|}{ Stage of lactation (SOL) } & SEM-SOL & \multicolumn{4}{|c|}{ Dietary CP, $\%$ of DM } & SEM-CP & \multicolumn{3}{|c|}{$P$-value ${ }^{1}$} \\
\hline $\mathrm{g}$ of $\mathrm{N} / \mathrm{d}$ per cow & 103.7 & 107.7 & 96.4 & 4.69 & 56.8 & 90.4 & 114.3 & 149.1 & 4.97 & 0.277 & $<0.001$ & 0.909 \\
\hline $\mathrm{g}$ of $\mathrm{N} / \mathrm{m}^{2}$ per $\mathrm{h}$ & 1.32 & 1.37 & 1.31 & 0.069 & 0.817 & 1.116 & 1.466 & 1.943 & 0.071 & 0.819 & $<0.001$ & 0.212 \\
\hline$\%$ of $\mathrm{N}$ intake & 14.5 & 15.8 & 17.3 & 0.59 & 11.6 & 15.2 & 16.9 & 19.8 & 0.68 & 0.009 & $<0.001$ & 0.607 \\
\hline
\end{tabular}

${ }^{1}$ Probability of a significant effect of stage of lactation or a linear or quadratic effect of dietary CP.

${ }^{2}$ Effect of dietary $\mathrm{CP} ; \mathrm{L}=$ linear and $\mathrm{Q}=$ quadratic trends.

${ }^{3} \mathrm{UUN}=$ urinary urea $\mathrm{N}$ excretion $(\mathrm{g} / \mathrm{d}$ per cow $)$. 


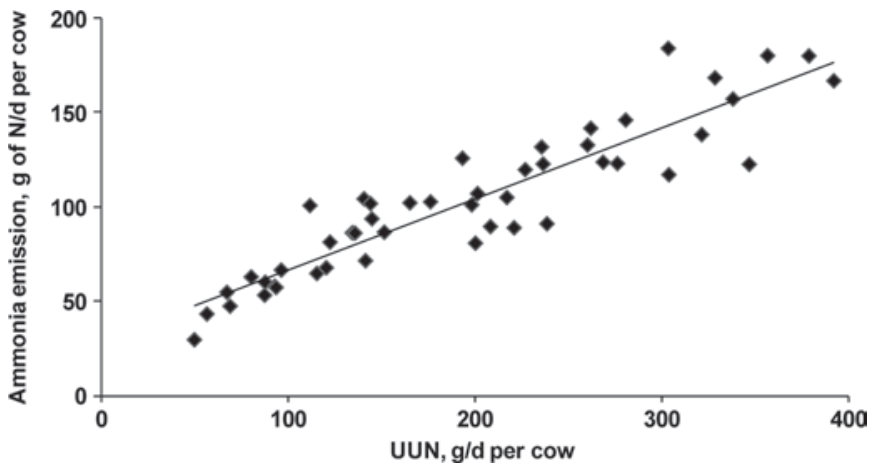

Figure 3. Ammonia emission (g of $\mathrm{N} / \mathrm{d}$ per cow) versus urinary urea N (UUN) excretion (g/d per cow). The $P$-values of all predicted estimates are $<0.0005$ and the standard errors are in parentheses. The solid line represents the regression equation [ammonia emission $=28.8$ $\left.( \pm 5.20)+0.377( \pm 0.024) \times \mathrm{UUN} ; \mathrm{R}^{2}=0.88\right]$.

ment was carried out for a longer period of time, there may not have been a decline in this ratio. As discussed previously, urea $\mathrm{N}$ in slurry was almost completely hydrolyzed within $24 \mathrm{~h}$ and TAN in the slurry increased as urinary urea increased relative to the amount of ammonia emitted. As the ammonia in slurry continues to equilibrate with the air above the slurry, the amount of ammonia emitted would become directly proportional to the amount of urea excreted because the initial step of ammonia emission (urea hydrolysis) is irreversible. Previous ammonia emission measurements from laboratory studies demonstrated that the majority (90\%) of ammonia was emitted within the first $26 \mathrm{~h}$ based on small samples $(<10 \mathrm{~g})$ of manure slurry (James et al., 1999). In our experiment, we used $1 \mathrm{~kg}$ of slurry in a container with a depth of $2 \mathrm{~cm}$, intended to represent the conditions in free stall barns. The depth and surface area of the container influences the release of ammonia and this likely underpins the differences between studies.

\section{Relationship of Ammonia Emission and UUN Excretion or MUN}

The relationship between ammonia emission and UUN excretion is presented in Figure 3 . The $P$-values of all predicted estimates in equations [2] and [3] are $<0.0005$ and the standard errors are in parentheses. Slopes of the ammonia emission and UUN excretion relationship were not different among lactation stages or between periods, so the relationship reduced to a simple equation as indicated in equation [2]:

$$
\begin{gathered}
\text { Ammonia emission }(\mathrm{g} / \mathrm{d} \text { per cow })=28.8( \pm 5.20) \\
+0.377( \pm 0.024) \times \text { UUN excretion }(\mathrm{g} / \mathrm{d} \text { per cow }) \\
\mathrm{R}^{2}=0.88
\end{gathered}
$$

This relationship supports the conclusion that as total grams of urea in the urine increase, the maximal amount of ammonia that can be emitted increases proportionally.

The main objectives of this experiment were to develop a relationship between ammonia emissions and MUN and to test whether the relationship was affected by stage of lactation. The relationship between ammonia emission and MUN is shown in Figure 4. The relationship between ammonia emission and UUN excretion was not different among lactation stages, so the relationship is described by equation [3]:

$$
\begin{aligned}
& \text { Ammonia emission }(\mathrm{g} / \mathrm{d} \text { per cow })=25.0( \pm 6.72) \\
& +5.03( \pm 0.373) \times \mathrm{MUN}(\mathrm{mg} / \mathrm{dL}) ; \mathrm{R}^{2}=0.85
\end{aligned}
$$

A strong correlation between ammonia emission from Holstein-Friesian dairy cows housed in a naturally ventilated barn and bulk tank milk urea concentration was initially reported by van Duinkerken et al. (2005), but the relationship was expressed in a form not directly comparable with the current study. Powell et al. (2008) developed a simple relationship between ammonia emissions and MUN based on emission measurement from 4 dairy cows housed in a tie-stall house and using weighted MUN values. The slope and intercept of the relationship by Powell et al. (2008) [ammonia emission $(\mathrm{g}$ of $\mathrm{N} / \mathrm{d}$ per cow $)=0.033+0.991 \times \mathrm{MUN}(\mathrm{mg} / \mathrm{dL})$; $\left.\mathrm{R}^{2}=0.27\right]$ is different than the one described in the present study. The average ammonia emission reported by Powell et al. (2008) was $11.3 \mathrm{~g}$ of $\mathrm{N} / \mathrm{d}$ per cow, whereas in this study it was about $102 \mathrm{~g}$ of $\mathrm{N} / \mathrm{d}$ per cow. This dramatic difference is likely attributable to experimental design.

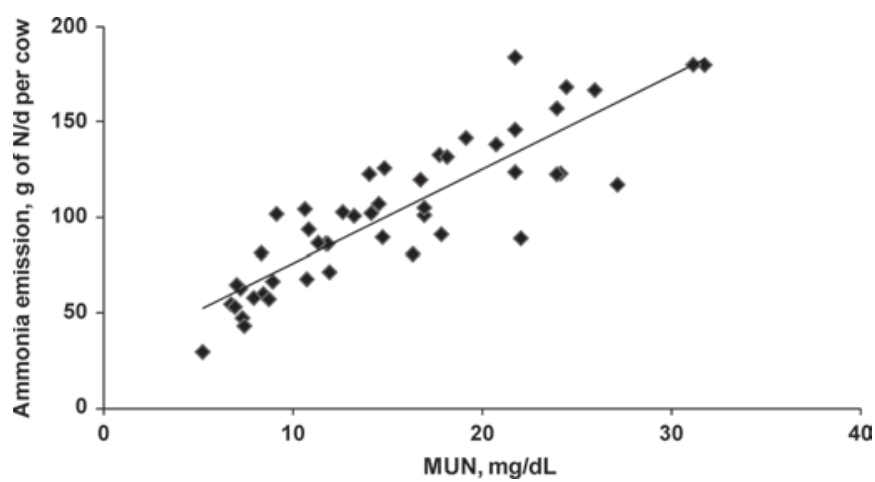

Figure 4. Ammonia emission (g of $\mathrm{N} / \mathrm{d}$ per cow) versus MUN $(\mathrm{mg} / \mathrm{dL})$. The $P$-values of all predicted estimates are $<0.0005$ and the standard errors are in parentheses. The solid line represents the regression equation [ammonia emission $=25.0( \pm 6.72)+5.034( \pm 0.3729)$ $\times$ MUN; $\left.\mathrm{R}^{2}=0.85\right]$. 
If ammonia emissions were regressed on MUN amount using techniques described elsewhere (Burgos et al., 2007), then the appropriate equation would be described by equation [4], but incorrect if a regression similar to equation [3] was used. The analysis showed that at least 1 stage of lactation had a different slope from the others and thus equation [4] is described below:

$$
\begin{gathered}
\text { Ammonia emission }(\mathrm{g} / \mathrm{d} \text { per cow })=28.3( \pm 8.36) \\
+\beta_{\mathrm{i}} \times \operatorname{MUN}(\mathrm{g}) ; \mathrm{R}^{2}=0.84
\end{gathered}
$$

where $\beta_{\mathrm{i}}=$ the slopes of the different stages of lactation. For early, mid, and late lactation stages the slopes would be $12.1( \pm 1.31), 17.5( \pm 1.97)$, and $22.1( \pm 2.68)$, respectively. These results would be interpreted similarly except stage of lactation would need to be considered. Further analyses would be required before using equation [4] and at least 2 regression equations would be needed to represent the different stages of lactation. This approach would be difficult to apply because the definition of stage of lactation is based on DIM, which may need to be adjusted if different diets are used. The importance of equation [4] is that the slope of higher producing cows is less than that of lower producing cows. This implies that as urea is distributed in the animal to milk and urine, higher producing cows would send less urea to the urine, and hence less manural ammonia emissions, relative to the amount of urea distributed to the milk. Therefore, cows producing more milk are more efficient in using nitrogen than cows producing less milk. Stage of lactation is not significant when using MUN concentration but is significant when using MUN amount to predict total ammonia emissions.

The current study was specifically designed to determine maximal ammonia emissions over $24 \mathrm{~h}$ under controlled conditions from slurries derived from manure of dairy cows fed diets varying widely in $\mathrm{CP}$ levels where the only difference between the diets was urea content. Under these conditions, MUN is linearly related to ammonia emissions from dairy cattle manure. Dietary factors, such as CP degradability and dietary fiber and salt content, may affect the relationship between MUN and UUN excretion. However, genetic and individual factors have been shown to affect MUN and UUN excretion rates (Lebzien et al., 2008). In addition, environmental conditions that affect urea hydrolysis, such as urease activity and $\mathrm{pH}$, as well as ammonia dissociation and mass transfer, such as temperature, $\mathrm{pH}$, and air velocity, will need to be accounted for in models that accurately predict ammonia emissions under practical conditions. As ammonia emission measurements under different conditions (i.e., dietary factors and environmental conditions) become available, it will be interesting to compare regression coefficients and integrate the data to develop robust predictive models. The widespread application of MUN as a tool to monitor ammonia emissions from dairy cattle will depend on standardization of MUN measurement methodologies because determination of MUN concentration can vary widely depending on the instruments and laboratories where it is analyzed (Kohn et al., 2004). Nevertheless, despite the significant differences in experimental conditions between the present study and Powell et al. (2008), a clear association between ammonia emissions and MUN was observed, suggesting that MUN may be a useful tool to predict ammonia emissions by dairy cattle.

\section{CONCLUSIONS}

The initial urea $\mathrm{N}$ concentration in manure slurries from cows fed a $21 \%$ CP diet was substantially higher than for those fed a 15\% CP diet because of a combined increase in urine volume and urea $\mathrm{N}$ concentration in urine. Regardless of initial urea $\mathrm{N}$ concentration in manure slurries, urea was hydrolyzed $>90 \%$ within $24 \mathrm{~h}$. The concentration of TAN in manure slurries increased substantially by $24 \mathrm{~h}$ as ammonia equilibrated between the boundary layer of the slurry and the air above. Ammonia emissions from dairy cattle manure slurries were not different between lactation stages, but increased linearly in response to $\mathrm{CP}$ levels. There was a strong relationship between ammonia emissions and MUN. This relationship was not different between stages of lactation. Milk urea N concentration is one of several factors that allows prediction of ammonia emissions from dairy cattle manure.

\section{ACKNOWLEDGMENTS}

The authors express their appreciation to S. J. Taylor (Department of Animal Science, University of California, Davis) for help with the laboratory analyses. This research was supported by the California Agricultural Experiment Station, the Dairy Milk Components Laboratory at the University of California, Davis, the California State Water Resources Control Board (Sacramento, CA), and the Merced County Department of Environmental Health (Merced, CA).

\section{REFERENCES}

Bannink, A., H. Valk, and A. M. van Vuuren. 1999. Intake and excretion of sodium, potassium, and nitrogen and the effects on urine production by lactating dairy cows. J. Dairy Sci. 82:10081018 .

Bristow, A. W., D. C. Whitehead, and J. E. Cockburn. 1992. Nitrogenous constituents in the urine of cattle, sheep and goats. J. Sci. Food Agric. 59:387-394.

Journal of Dairy Science Vol. 93 No. 6, 2010 
Broderick, G. A., and M. K. Clayton. 1997. A statistical evaluation of animal and nutritional factors influencing concentrations of milk urea nitrogen. J. Dairy Sci. 80:2964-2971.

Broderick, G. A., N. D. Luchini, S. M. Reynal, G. A. Varga, and V. A. Ishler. 2008. Effect on production of replacing dietary starch with sucrose in lactating dairy cows. J. Dairy Sci. 91:4801-4810.

Burgos, S. A., J. G. Fadel, and E. J. DePeters. 2007. Prediction of ammonia emissions from dairy cattle manure based on milk urea nitrogen: Relation of milk urea nitrogen to urine urea nitrogen excretion. J. Dairy Sci. 90:5499-5508.

Bussink, D. W., and O. Oenema. 1998. Ammonia volatilization from dairy farming systems in temperate areas: A review. Nutr. Cycl. Agroecosyst. 51:19-33.

Cassel, T., L. Ashbaugh, R. Flocchini, and D. Meyer. 2005. Ammonia emission for open-lot dairies: Direct measurements and estimation by nitrogen intake. J. Air Waste Manage. Assoc. 55:816-825.

Colmenero, J. J., and G. A. Broderick. 2006. Effect of dietary crude protein concentration on milk production and nitrogen utilization in lactating dairy cows. J. Dairy Sci. 89:1704-1712.

DePeters, E. J., and J. D. Ferguson. 1992. Nonprotein nitrogen and protein distribution in the milk of cows. J. Dairy Sci. 75:31923209.

Elzing, A., and G. J. Monteny. 1997. Ammonia emission in a scale model of a dairy-cow house. Trans. ASAE 40:713-720.

Frank, B., and C. Swensson. 2002. Relationship between content of crude protein in rations for dairy cows and milk yield, concentrations of urea in milk and ammonia emissions. J. Dairy Sci. 85:1829-1838.

Gustafsson, A. H., and D. L. Palmquist. 1993. Diurnal variation of rumen ammonia, serum urea, and milk urea in dairy cows at high and low yields. J. Dairy Sci. 76:475-484.

James, T., D. Meyer, E. Esparza, E. J. DePeters, and H. PerezMonti. 1999. Effects of dietary nitrogen manipulation on ammonia volatilization from manure from Holstein heifers. J. Dairy Sci. $82: 2430-2439$.

Jonker, J. S., R. A. Kohn, and R. A. Erdman. 1998. Using milk urea nitrogen to predict nitrogen excretion and utilization efficiency in lactating dairy cows. J. Dairy Sci. 81:2681-2692.

Kauffman, A. J., and N. R. St-Pierre. 2001. The relationship of milk urea nitrogen to urine nitrogen excretion in Holstein and Jersey cows. J. Dairy Sci. 84:2284-2294.

Kohn, R. A., K. R. French, and E. Russek-Cohen. 2004. A comparison of instruments and laboratories used to measure milk urea nitrogen in bulk-tank milk samples. J. Dairy Sci. 87:1848-1853.

Kröber, T. F., D. R. Kulling, H. Menzi, F. Sutter, and M. Kreuzer 2000. Quantitative effects of feed protein reduction and methionine on nitrogen use by cows and nitrogen emission from slurry. J. Dairy Sci. 83:2941-2951.

Lebzien, P., W. Brade, and G. Flachowsky. 2008. Milk urea content: An indicator for energy and protein supply as well as for the emission of nitrogen from dairy cattle. Übers. Tierernährg. 36:59-74.

Littell, R. C., G. A. Milliken, W. W. Stroup, and R. D. Wolfinger. 1996. SAS Systems for Mixed Models. SAS Inst. Inc., Cary, NC.
Marsh, W. H., B. Fingerhut, and E. Kirch. 1957. Determination of urea nitrogen with diacetyl method and an automatic dialyzer apparatus. Am. J. Clin. Pathol. 28:681-688.

Misselbrook, T. H., J. M. Powell, G. A. Broderick, and J. H. Grabber. 2005. Dietary manipulation in dairy cattle: Laboratory experiments to assess the influence on ammonia emissions. J. Dairy Sci. 88:1765-1777.

Monteny, G. J., and J. W. Erisman. 1998. Ammonia emissions from dairy cow buildings: A review of measurement techniques, influencing factors and possibilities for reduction. Neth. J. Agric. Sci. 46:225-247.

Muck, R. E. 1982. Urease activity in bovine feces. J. Dairy Sci. 65:2157-2163.

Muck, R. E., and T. S. Steenhuis. 1980. N losses in free stall dairy barns. Pages 406-409 in Livestock Waste: A Renewable Resource. Proceedings 4th Int. Symp. on Livestock Wastes. ASAE, St. Joseph, MI.

Noel, R. J., and L. G. Hambleton. 1976. Collaborative study of a semiautomated method for the determination of crude protein in animal feeds. J. Assoc. Off. Anal. Chem. 59:134-140.

NRC. 1989. Nutrient Requirements of Dairy Cattle. 6th rev. ed. Natl. Acad. Sci., Washington, DC.

Paul, J. W., and E. G. Beauchamp. 1989. Relationship between volatile fatty acids, total ammonia and $\mathrm{pH}$ in manure slurries. Biol. Wastes 29:313-318.

Paul, J. W., N. E. Dinn, T. Kannangara, and L. J. Fisher. 1998. Protein content in dairy cattle diets affects ammonia losses and fertilizer nitrogen value. J. Environ. Qual. 27:528-534.

Pfaff, J. D. 1993. Method 300.0: Determination of inorganic anions by ion chromatography. Rev 2.1. Office of Research and Development, US Environmental Protection Agency, Cincinnati, $\mathrm{OH}$.

Powell, J. M., G. A. Broderick, and T. H. Misselbrook. 2008. Seasonal diet affects ammonia emissions from tie-stall dairy barns. J. Dairy Sci. 91:857-869.

Sannes, R. A., M. A. Messman, and D. B. Vagnoni. 2002. Form of rumen-degradable carbohydrate and nitrogen on microbial protein synthesis and protein efficiency of dairy cows. J. Dairy Sci. 85:900-908

SAS Institute. 1999. SAS User's Guide: Statistics. Version 8.2. SAS Inst. Inc., Cary, NC.

Sun, H., Y. Pan, Y. Zhao, W. Jackson, L. Nuckles, V. Arteaga, and F. M. Mitloehner. 2008. Effects of sodium bisulfate on alcohol, amine, and ammonia emissions from dairy slurry. J. Environ. Qual. 37:608-614.

van der Stelt, B., P. C. J. van Vliet, J. W. Reijs, E. J. M. Temminghoff, and W. H. van Riemsdijk. 2008. Effects of dietary protein and energy levels on cow manure excretion and ammonia volatilization. J. Dairy Sci. 91:4811-4821.

van Duinkerken, G., G. Andre, M. C. J. Smits, G. J. Monteny, and L. B. J. Sebek. 2005. Effect of rumen-degradable protein balance and forage type on bulk milk urea concentration and emission of ammonia from dairy cow houses. J. Dairy Sci. 88:1099-1112. 